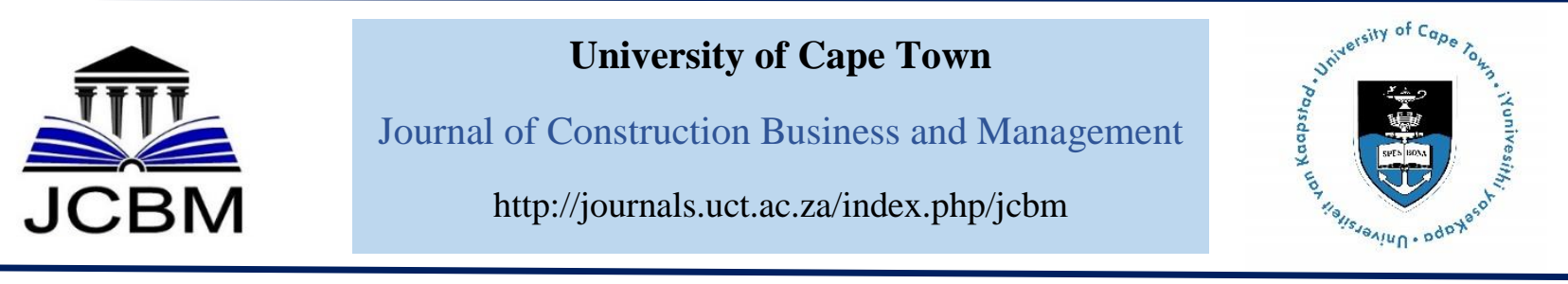

\title{
A State Legitimation Approach of Reserved Built Environment Professional Work - A Case for South Africa - Part 1
}

\author{
T. E. Manchidi ${ }^{1}$, P.D. Rwelamila ${ }^{2}$ \\ ${ }^{1 \& 2}$ Graduate School of Business Leadership, University of South Africa, South Africa.
}

Received 11 April 2019; received in revised form 21 May 2019, 2 july 2019; accepted 15 July 2019 https://doi.org/10.15641/jcbm. 3.2.740

\begin{abstract}
This paper borrows from the lenses of the sociology of professions, sociology of science, temporary project organisations and construction reform to examine state legitimation of reserved built environment (BE) professional work as the first part of a two-part study. In doing so, it examines the growth of professions as a consequence of the division of expert labour evolving to fill in knowledge gaps created by emergent social forces as other knowledge areas are rendered less relevant. It shows how BE professional work negatively impacts on the delivery efficiencies in the project as a temporary organisation. In making this argument, it draws on the jurisdictional theory of professions to illustrate the relational and interactional relationship of professions in construction projects. To help focus on collaboration, a preliminary conceptual model for the legitimation of professions at the macro (policy) level is developed to explain how boundary margins keep professions relational, and how the dynamics of boundary work unfold in a territorial space in a project (meso) environment. Finally, it provides the scope of the second part of the study (the field study) by formulating the main research objective and research question and their respective specific research objectives and research questions, respectively.
\end{abstract}

Keywords: Built Environment Professions, Division of Expert Labour, Jurisdictional Boundaries, Legitimation, Professional Work, Temporary Organisations

\section{Introduction}

Construction industries (CIs) around the world, relative to other industries, face problems of inefficiency, ineffectiveness and sub-optimal performance. Improvement in the performance of the CIs that delivers infrastructure and facilities that forms the built environment is crucial for social and economic development, and environmental protection, especially in developing countries (WEF 2016; Gann and Salter 2000). In response, there has been calls for bold action for over half a century by governments, multilateral agencies; and other stakeholders, focusing on to improving construction productivity, quality of products and services, innovation; and reversing the negative trajectory facing the CI (Fox, 2003, Ofori, 2011, Hermans, van Zoest, and Volker, 2016).

Built Environment Professions (BEPs), as one of the significant constituents in the CI, deserve consideration, as they temporarily collaborate and integrate their specialised knowledge in the delivery of projects (D'Amour and Oandasan 2005; McMurtry 2013). They provide vital specialised knowledge and technical skills that are used in the planning, design, construction supervision, maintenance and eventual disposal of assets in the BE (Ampofo-Anti, 2007). However, questions have been raised as to the role of the BEPs in the poor performance of the CI. For example, Eccles (2009:68) queried "...whether they are part of the industry's economic problems". Such a question is not uncommon when addressing the role of any other professions. Equally, Dingwall and Fenn (1987: 51) asked: are these occupations monopolies whose anticompetitive effects distort the social and economic organisation of a society or are they institutions which have developed for reasons of public interest and are, therefore, worthy of preservation? The process of transforming from occupations to professions is referred to as

\footnotetext{
${ }^{1}$ Corresponding Author.

Email address: eric@pdconsulting.co.za
} 
professionalisation, and this reflects 'how modern societies institutionalize expertise' (Abbott, 1988; Evetts, 2012). Various theories of professions, as shown later, maintains that the objectives of professionalisation differ from occupational closure to public interest. Noordegraaf (2006:765) notes that we lack widely available conceptual frameworks for understanding these complicated processes of professionalisation.

These are important questions that encourage the need to question the relevance of BEPs as the CI does not appear to fully benefit from the division of expert labour (DoEL), which is the core reason for the existence of specialisation through BEPs. While the role of professionalism in society is generally seen as relevant, its potential future in the CI is being challenged as not so much has surfaced from BEPs (Eccles 2009; Hughes and Hughes, 2013). It is in light of this that this study seeks new insight into the legitimation of any reserved Built Environment professional work that could offer new avenues for addressing problems facing the CI as part of the broader CI reform agenda.

\section{Literature Review}

\subsection{The concept of legitimation of $\mathrm{BE}$ professional work}

The authors find it convenient to advance the discussion on existing models for professionalisation by referring to two processes of framing professionalisation that grants a different form of exclusivity.

- Reservation or protection of title where any member of the public can carry out the functions of a profession without being registered with the appropriate regulatory body provided s/he does not hold himself/herself under specific title reserved for the professional. Otherwise, it becomes a criminal offence to use the reserved title that is protected by the law.

- Reservation of professional work or protection of functions where reserved functions (also called controlled acts or reserved work) are the sole province of specific professionals registered with the regulatory body. By reserving the services, the state limits the practice of such professional work to the categories of registered persons who would have met specific requirements on the basis that they are protecting the public from incompetent and unethical practitioners. Where there is the protection of functions, it becomes a criminal offence to carry out, such without being registered with the relevant regulatory body.

The practice of reservation of professional work, is in itself not a widely utilized tool, the reason being that it is often not possible to clearly define the functions which are to be limited to registered professionals without some ambiguity (HPC, n.d). Identification of work (IDoW) is one such form of reservation of built environment professional functions in South Africa emanating from statutory regulation of BEPs. To date, fewer studies have accounted for the relational interaction in this fractal divide. Therefore, there is limited information about what what occurs as a result of reservation of professional work, in terms of the boundary margin effect (discussed later herein). Though academic literature on professions argues a strong case for the structuring of expertise in society through professions (e.g. Adler et al., 2008) it does little to address the structure of their professional work.

The concept of legitimacy is defined by Suchman (1995:574) in Hughes an Hughes (2013) as "a generalized perception or assumption that the actions of an entity are desirable, proper, or appropriate within some socially constructed system of norms, values, beliefs and definitions".

Reservation or protection of functions deserves consideration in the construction reform agenda, especially in developing countries wherein the catalogue of problems facing CI include: lack of human resources, institutional capacity and limited human capacity development (Ofori, 2000,2011; van Wyk, 2006). This is accompanied by a lack of appropriate policies and strategies addressing the development of BEPs, which raises the question as to why very little attention is given to BEPs. This is important, as professions are one of the institutions through which the society hold the expertise, in addition to 'organisations' and 'commodification' (Abbott, 1988:323). Hence, BEP policy frameworks are devised and implemented as "machinery and mechanisms necessary to achieve reform" (CIB, 2011) in developing countries.

Given the above, the Anglo-American sociology of professions where the state is just an "actor" and part of "large social force" involved in endorsing the outcomes of the professionalisation process becomes redundant in the state-led construction reform. This is because governments in developing countries, through public policies actively define professional jurisdiction, as is the case in the continental European countries such as France, Italy and Germany where the state acts as a "creator of professional jurisdictions" by granting privileges through legislation (Le Bianc 2003). Such an approach is supported by Liu's (2016) argument that for developing countries, the social spaces of professions and [CI] development are overlapping ecologies that share some common actors. This study is done towards providing a possible conceptual model that will improve the state regulation of renewed and emerging BE professional work in South Africa, and by so doing improve the BEPs' performance in project delivery.

\subsection{Built environment professions in the CI}

There are many definitions of profession arising out of mostly sociology and economic literature are influenced by the theoretical approaches that different authors follow. The description of a profession is given in Langford and Hughes (2009) as a body of knowledge to ensure an evenness of standards of services to the public. For this paper, professions are defined as knowledgebased occupational groups that share tangential boundaries with other occupations, with abstract knowledge being one of the key distinguishing factors.

It is noteworthy that the term "BEPs" is inconsistently defined across the world. However, it is a noun mostly used as an umbrella name for construction, property and facilities management professions. The literature does not offer a definite list of BEPs as it is a drifting concept that varies from country to country and from period to period (Haigh and Amaratunga 2010, Muir and Rance 1995, Hartenberger et al., 2013). The BEPs are best defined by 
first defining the two terms: built environment (BE) and professions; in addition to the concept of division of expert labour (DoEL) described herein.

The BE is as an interdisciplinary field, where each discipline is defined as a branch of scientific knowledge, that cuts across planning, design, production, adaptation, maintenance, restoration, conversation, management, evaluation and recycling of the BE (CIOB 2010, Chynoweth 2006 \& 2009). These disciplines comprise specialisms, some of which share standard features, and the boundaries between disciplines and relationships amongst them are ill-defined and continuously changing (Wagner at al., 1991 cited in Ofori, 1994).

\subsection{BEPs as a result of division of expert labour}

Division of labour (DoL) in a society is both a classical social and economic phenomenon studied by several classic writers including Adam Smith in 'The Wealth of the Nation' (1779) and Emile Durkheim in 'The Division of Labour in Society' (1893). According to Smith 's division of labour theory, production efficiencies increase with task separation, where one worker is repeatedly performing each task as compared to where the functions are combined across the value chain and conducted by the same worker. Adam Smith's proposition was further qualified by saying that "the extent of the market" limits the Division of Labour. In effect, this means that the expansion of the scale of DoL is dependent upon the market. Put differently, the bigger the market, the more the DoL. In Smithian theory, therefore DoL is driven by pure economies of scale (not forgetting the opportunity cost of coordinating a long list of specialists in the value chain). Stigler (1951) echoed Smith's theory to say as an industry grows vertical disintegration occurs where different cost functions become involved in the different aspects of the production of goods.

BEPs can best be represented by the tracing of their historical path from craft guilds to master builders and ultimately to the modern professions as we know them. While such a review is outside the scope of this paper, there are, however, two views concerning the relationship between the development of modern BEPs in general and the craft guilds in particular that deserve attention. The first view is that modern BEPs is an extension of the medieval crafts where all major crafts were organised into guilds, which regulated their affairs and controlled entry to the crafts (Bellis, 2000; Krause, 1996). Just like BEPs, guilds practice monopolistic competition and occupational domination over the trades. The main difference, however, is that guilds included semiprofessional occupations with fewer knowledgeecologies than professions. The second and opposing view is that modern BEPs are not a continuity of the older guilds but rather a break from that tradition. The BEPs appeared in the 19th century as the powers of the guilds were slowly being eroded by significant shifts in political and economic institutions, such as the growth of centralised forms of government, erosion of monarchical powers and increasing commitment to free markets. These changes culminated into the industrial revolution, and different patterns of economic resource and wealth distribution from that in the middle ages (Dingwall, 1996). In the case of occupations, professionalism became a form of the modernisation process identified by "the advance of science and cognitive rationality and the progressive differentiation and rationalization of the division of labour in industrial societies" (Larson, 1977: xiii).

The evolution of BEPs thus seems to support the view that craft guilds were precursors to BEPs and that the emergence of professions was a response to the increasing complexity brought about by industrialisation and sustained by present-day technological, economic, environmental, social and sustainable challenges (Hughes and Hughes 2013). According to Krause (1999) cited in Henn (2013), craft guilds are said to have heralded the beginnings of claims of expertise and professionalism in BE. Thus, the CI experienced DoEL due to the growth of the market (Henn 2013). As the buildings became more complex, disciplines were developed in response and professionals acquired expert knowledge, standard credentials and status in the society.

Today, BEPs as a form of specialisation accompanied by DoEL continue to grow as organisational and technological changes continue to lead the production process and render some knowledge requirements obsolete (Gann and Salter 1999). They also shift the knowledge boundaries of professions and sometimes gives birth to new ones while continuing to fragment existing ones further (Abbott, 1988; Henn (2013) and Hughes and Hughes (2013).

\subsection{Fragmentation as an impact of temporary project organisation structures}

Projects-as a sphere where BE professional work is practised-call for better coordination of expertise to attain effective working relationships and benefit from specialisation. According to Jones \& Lichtenstein (2008), a project is a nexus of activities that allows multiple and temporary project-based organisations to work together to achieve their individual and collective goals in a limited period. The temporariness is key as projects are resourced through professionals employed in firms and only come together to execute a one-time project. Hindle (1988) refers to Higgin and Jessop (1985) in arguing that the central problem facing the $\mathrm{CI}$ is that the relationship that exists among the resource controllers, professions included, is that of interdependent autonomy, with no match between technical and organisational interdependence. This suggests that the temporary organisation of the resources into a project structure is far removed from the organisations that employ the professionals. This temporary arrangement nullifies the benefits gained through DoEL and specialisation and perpetuates the problems that do not appear in established ongoing production organisations. Table 1 lists some of the problems.

As such, the institutionalised arrangements of organizing BE professional work in projects deserve to be more widely recognised for their role in shaping projects. Powell (1990) cited in Bechky (2006:327) proceeds further to reveal that "we know very little about the phenomenology of work within temporary organisations". As such Bechky (2006:327) picking on Powell (1990) raises a relevant question about "how people cope with circumstances in which control is not direct and 
immediate, and conformity to well-established administrative routines not guaranteed".

Table 1: Problems that plague temporary organisations

\begin{tabular}{ll}
\hline Problem & Reference \\
\hline $\begin{array}{l}\text { Inherent transaction costs } \\
\text { Working in new teams that }\end{array}$ & $\begin{array}{l}\text { Turner and Müller } \\
\text { constantly shift team } \\
\text { membership and }\end{array}$ \\
$\begin{array}{l}\text { leadership } \\
\text { lack of co-operation, trust, } \\
\text { effective communication } \\
\text { and adversarial } \\
\text { relationships }\end{array}$ & $\begin{array}{l}\text { Demsetz (1991); } \\
\text { Thomassen (2004); } \\
\text { new disciplines render } \\
\text { established ones obsolete }\end{array}$ \\
\hline
\end{tabular}

Bechky's (2006) observation points out a need to understand BE professional work in these short-lived project" settings due to the following features of functionally interdependent professional practice bringing in the fragmentation effects in the $\mathrm{CI}$ :

i. temporary collaboration and integration of their knowledge (McMurtry, 2013);

ii. Interconnection and intertwinement as they cannot deliver their functions independently (Abbott 1988; Bordass \& Leaman, 2013); and

iii. The accomplishment of tasks is by forming an ecology of occupations (Janda and Killip, 2010).

Fragmentation is a common phenomenon blamed for inefficiencies in the CI. Many industry reports and studies (e.g. Emmerson, 1962; Latham, 1994; Egan, 1998; Construction Industry Review Committee, 2001) proximate fragmentation to a dirt work blamed for and a significant contributor to a wide range of problems facing the CI. Some of the problems facing the CI are listed in Table 2.

Table 2: Problems associated with fragmentation in the CI

\begin{tabular}{ll}
\hline Problem & Reference \\
\hline $\begin{array}{l}\text { lagging behind in absorption of } \\
\text { new technologies and } \\
\text { Innovation }\end{array}$ & $\begin{array}{l}\text { Eichert and Kazi, } \\
2007\end{array}$ \\
\hline $\begin{array}{l}\text { poor quality, bad service and } \\
\text { broken promises }\end{array}$ & $\begin{array}{l}\text { Egan, 1998; Wood, } \\
\text { McDermott, and } \\
\text { Swan, 2002 }\end{array}$ \\
\hline & Kadefors, 2004; \\
$\begin{array}{l}\text { Difficulties in communication, } \\
\text { co-operation and integrated } \\
\text { project practices }\end{array}$ & $\begin{array}{l}\text { Dainty et al., 2006; } \\
\text { Winch, 2010; }\end{array}$ \\
\hline & Gustavsson and \\
& Gohary, 2012).-------.
\end{tabular}

Over the wall" syndrome - a

disconnection between design and construction through a sequential approach to project

Evbuomwan and Anumba 1998

development

In the practical sense fragmentation "means that the ownership and control of separate functions ... resides in the hands of separate organisations with their own distinctive cultures and working practices" (Oranje et al., 2005:131). Just like in the case of DoEL, there is widespread agreement among scholars and practitioners that the root cause of fragmentation was grounded on the broader phenomenon of industrialization and increasing project size, scope and complexity (Henn, 2013). As a result, the CI does not fully enjoy the benefits of DoEL but instead suffer from the fragmentation, which defines boundaries, rules of interaction and division of responsibilities (Hoffman and Henn, 2008).

While horizontal fragmentation represents differentiation into specialist disciplines, the frustration, however, is that most of the occupational groups resulting from these disciplines do not see themselves as being part of a more extensive professional network responsible for delivering projects (Hartenberger, 2013). According to Alashwal and Abdul-Rahman (2013), the CI contains little network closures. As such, many structural holes are caused by fragmentation. Contrary to the sweeping view, Bresnen and Marshall (2001) supported by Tobin (2015) demonstrate that fragmentation itself is not necessarily a problem, but it is the lack of integration and coordination of the fragments that are a problem. A similar view is held by Zürn and Faude (2013) that it is not fragmentation per se, but rather the coordination (or lack of it) of fragmented or differentiated institutions. Specialism is, however, unavoidable as projects become more complex and become augmented by technological, economic and other external factors (Kallip and Jindal, 2013; Henn, 2013).

Hindle (1998 \& 2015) blames professions and even questions as to whether professions create segmentation or specialisation. His position is supported by Eccles (2012) who views the Royal Charters and statutes establishing professions as encouraging fragmentation by creating jurisdiction. Their argument is supported by the fact that each profession acts independently and has a separate identity. They become defensive of their various professional turfs or institutions and want to maintain their independence (Fairclough, 2002). From this perspective, the root cause is the assertion of individual identity and independence, resulting in specialisation without proper coordination.

Hindle (2015) and Eccles (2012) argue that one way of realising collective identity and improving coordination in professions is to pursue similarities in work practice and procedures; in other words, finding a common way of perceiving the problems and their possible solutions and sharing methods, thus bringing in the normative value system of professionalism in professional work and workplaces. Consistent with the above view, Edwards (2010) argues that practice is a 'relation agency' phenomenon in a knowledge-driven institutional setting such as projects. It involves practitioners bringing their knowledge to complex problems, a capacity to negotiate what matters to other professionals and aligning with them in this collaborative, complex phenomenon. Therefore, a practice of professions means performance with professionalism by professionals, of their professional services in a work environment.

However, that being the case, Freidson (1989:439) suggests that we know little about professional practice the organization of professional work and the way it is performed - is by far the weakest. Freidson (1989), therefore calls for a systematic look at a professional practice that we can understand what work is done, how 
and why." Freidson (1989:439). Freidson views, therefore, practice as an organisation and regards the study of the various forms of professional practice as a critical requirement for developing not an only better understanding of the professions but also sensitive and intelligent social policies for dealing with them. To this effect, Gurrie (2009) advises that the organisation and management of professional work remains a significant area of analysis, which will be relevant to construction reform.

\subsection{Sociological Theories of Professions}

Table 3: Perspectives on sociological theories of professions

\begin{tabular}{|c|c|c|}
\hline $\begin{array}{l}\text { Theoretical } \\
\text { Perspective }\end{array}$ & Key Writers & Key Features \\
\hline Traits & $\begin{array}{l}\text { Carr-Saunders and Wilson } \\
(1933) \\
\text { Caplow (1954) } \\
\text { Wilensky (1964) }\end{array}$ & $\begin{array}{l}\text { - Distinguishing characteristics or attributes of modern professions } \\
\text { from ordinary occupation. } \\
\text { key traits include possession of abstract knowledge and adherence } \\
\text { to code of conduct to altruistic service to the public }\end{array}$ \\
\hline $\begin{array}{l}\text { Structural } \\
\text { functionalism }\end{array}$ & Talcott Parson (1939) & $\begin{array}{l}\text { - Concerned with how structural relationships interconnect and the } \\
\text { functioning whole of the professions. } \\
\text { - Justification of the professional - client relationship on the basis } \\
\text { of the asymmetry of knowledge between the two. }\end{array}$ \\
\hline Power & $\begin{array}{l}\text { Everett Hughes (1971) } \\
\text { Elliot Freidson (1970) } \\
\text { (Johnson } 1972 \\
\text { Magali Larson, 1977) }\end{array}$ & $\begin{array}{l}\text { Professions use their possession of scarce knowledge and skill to } \\
\text { claim social recognition and economic rewards; } \\
\text { Professions use specialised knowledge for functional closure and } \\
\text { monopolisation to enhance their private interest. }\end{array}$ \\
\hline $\begin{array}{l}\text { Jurisdictional } \\
\text { Conflict }\end{array}$ & $\begin{array}{l}\text { Bucher and Strauss (1961) } \\
\text { Thomas Brante (1988) } \\
\text { Andrew Abbott (1988) } \\
\text { Edman (2001) }\end{array}$ & $\begin{array}{l}\text { - Professions engage in power struggle with other professions in the } \\
\text { same field for interactional and relational (territorial) space over } \\
\text { professional work; } \\
\text { - Regards professionalisation as a process of interprofessional } \\
\text { competition for jurisdictional expansion }\end{array}$ \\
\hline
\end{tabular}

The jurisdictional conflict focuses on social interaction or the reciprocal relationship between professionals in the workplaces (Abbott, 1986, 1988; Liu, 2014). An approach such as this is viewed to be interactional as it elevates the unit of analysis from individual professionals to competing professional groups which coexist in an ecological system (Liu, 2013). The struggle to monopolize jurisdictions in professions is viewed as an inter-professional competition over control of professional work within the field in which they operate. According to jurisdictional theorists, professions engage in a boundary formation over turfs as they patrol their borders from being "invaded" or encroached by neighbours; expand their boundaries into the neighbouring professions' turf; or occupying unclaimed space (vacancies). Unlike power theorists, jurisdictional conflict theorists are not concerned with the monopoly of an individual profession but rather the interaction of competing professions within the same field that share some form of expertise. Professions do not engage in a power struggle for domination, but for interactional space (territory) to compete with one another and constitute various jurisdictional settlements.

Unlike other theorists who put an over-emphasis on macro-sociological processes and the institutional forms of professionalism, jurisdictional conflict theorists focus on control of professional work and link them within an evolving field or system. Just like structural
The sociological theories of professions can be explored from at least four different perspectives: trait, structural functionalism, power and lastly jurisdictional conflict as summarized in Table 3 . These theories are not discussed in detail due to space limitations, except the jurisdictional/conflict theory, which forms the theoretical framework for this study. Briefly, trait and structural functionalism theories view professions as a positive aspect of modernism while power theory takes a negative view of professionalism, holding the view that professions are a form of monopolization and social closure aimed at dominating the market. functionalists, they are concerned with intra-group functioning and structures of differentiated professions in a whole of professions, rather than that of an individual profession. The jurisdictional theory considers differentiation of functions and a mechanism to bridge such structures to realise what Parsons (1968) calls a professional complex or what was later termed a system of professions by Abbott (1988). As suggested by Bechky (2003) that functional interaction at the level of work should be examined and shows how such negotiation of professional work boundaries occurs at the level of work.

The first jurisdictional theorists are said to be Bucher and Strauss (1961) who introduced the notion of professions as always in process, instead of static formations, and subject to divisions or segmentation when new specializations are developed. In particular, this study appropriates Abbott's System of Profession Model as a theoretical lens for viewing such interaction and relational agency.

\subsection{Abbott's system of professions as a theoretical lens}

Abbott's System of Professions Model provides a threelevel approach of "thinking about division of labour" and tends to "suggest a path to the study of work" (1988;317). It refers to the upper level, i.e., the broad social forces and how such forces affect individual professions under certain conditions; the middle/meso level where a system 
of profession is taken to be 'structures linking professions with task' (1988:315); and the bottom/micro level i.e. differentiation within professions themselves.

Abott's model is based on the legal concept of jurisdictions of professions within the same ecological space (biological and spatial concept) where domain provides a connection between a profession and its work. Jurisdiction is a concept defining the link between a profession and its work (Abbott 19988: 20). It is based on the idea that professions constitute an interactive ecology (Abbott 2005:246). Professions are seen as interacting in a limited social space called an ecological system where each profession is allocated a specialised area of professional work called jurisdiction in terms of the expert knowledge system that demarcates symbolic internal boundaries (Abbott 1988; 2005). This paves the way for a conception of an abstract social space borrowed from physical urban spaces and applied to sociology of professions. By an ecology, what is meant is a 'social interaction' that is best understood in terms of interactions between multiple elements that are neither fully constrained nor fully independent (Abbott 2005: 246).

Abbott argues that professions in the same ecological space do not exist alone but co-exist within a continuum in the system (i.e. act as a whole) where "Each profession is bound by a set of tasks and Jurisdiction" (1988:33). This 'system', is a complex, dynamic and interdependent structural network of a group of professions within a given domain of work, continually struggling over areas of knowledge and skill expertise (Abbott, 1988). The professions within the system are bonded or strained by "common work" or "common workplace" (1988:124) implying that they are both interactional and relational to another within the space provided". Since jurisdiction is exclusive, professions constitute an interdependent system (Abbott 1988: 86).

Accordingly, "professions are exclusive occupational groups applying somewhat abstract knowledge to particular cases" (Abbott 1988:8). Abbott argues that the power of professions is rooted in their body of knowledge, which should be sufficiently abstract to prevent appropriation by other professions. The jurisdiction establishment and claim process in Abbott's system of professions underlines a vital feature of any profession, which is that professions are interdependent and therefore must recognise each other to build a recognisable system of legitimate claims in the workplace. Abbott argues that the struggle to monopolise jurisdictions in professions is an inter-professional competition over control of professional work. Professions regularly engage in interprofessional turf battles with each other for jurisdictions. The conflict arises out of professions protecting the monopoly of their settled jurisdiction from invasion by outsiders or other professions within the system, crossing boundaries into their territories.

Abbott's System of Professions Model is seen as relevant to the study of BE professional work for several reasons. First, Abbott (1998:325) recommends that "[We] must stop studying single professions ... and start studying work." This is because "professions both 'created their work and created by it [work] 1998:325'. In Abbott's (1988:19) opinion:
"It is control of work that brings the professions into conflict with each other and makes their histories interdependent'. It is differentiation in types of work that often leads to acute differentiation within the professions. By switching from a focus on the organisational structures of professions to a focus on groups with typical work, several assumptions are replaced at once."

Second, Abbott's System of Professions Model makes a substantial contribution to the better understanding of professional jurisdictions where professions are mutually dependent and form an ecological system. He recognises that "a profession's success reflects as much the situation of its competitors and the system structure as it does the profession's effects" (Abbott 1988:33). According to Liu (2009: 2014), Abbott's model is said to be a fundamental paradigm shift from previous sociological theories of professions because:

- It elevates the unit of analysis from single professions to a system of professions;

- It shifts from institutional structures of professions to professional work; and

- adopts an interactional and systematic relations approach (Liu, 2009; 2014).

Third, Abbott's (1988) model covers professions at the system level and further analyses the internal differentiation, structures and power of professions within the system as a result of how 'large social forces' affect the system and individual professions within the system. Abbott (1988) argues that organisational efficiency is a central value in the social-structural legitimation of professions. In so doing, he moves away from the institutional form of professionalism to focus on control of professional work within a constantly evolving system (Bureau and Suquet, 2009). He is concerned about structures and the intragroup functioning of differentiated professions in the system rather than of individual profession. He partially addresses Bechky (2003), who suggests that occupational interaction at the level of negotiation of work boundaries should be examined.

However, there are several weaknesses with Abbott (1988)'s model. Firstly, as construction literature on fragmentation demonstrates, boundaries of professions have continuously shifted and required incessant 'boundary work' by those who are interested in ascertaining the professional identity and the productive status of the boundary margins on professional work. Despite all of the above, Abbott still does not answer the question that begs to be asked: How does a system of interdependent professions organize its coordination? Here is where the jurisdictional conflict bias in Abbott's the System of Profession ceases posing questions about the characteristics of a system, that is working together as parts of an interrelated whole (displaying holism characteristics). Secondly, Abbott's theory focuses on conflicts arising out of jurisdictional boundaries and vacancies; and seems to lack a mechanism of articulation between different professions once they are created and competing for turf. While Abbott recognises the collective work as the basis of the conflict, he fails to recognise the potential of better co-ordination of such interdependence as a source of organisational efficiency in the legitimation of professions. Abbott is more concerned with social closure of one profession by another or monopolisation by 
expanding the boundaries of existing professions rather than the actual cooperation required in the professional work.

In summary, Table 4 outlines the relevance and criticism of the Abbottian Model in relation to $\mathrm{BE}$ professional work. While this theory is relevant, it is not sufficient to understand the extent to which professional work in a temporary organisation environment occurs. Direct extrapolation from this theory, to the extent that it enables the legitimation of reservation of professional work in the BE, is therefore impossible - as pinpointed by the limitations in the Table below.

Table 4: Relevance and criticism of the Abbottian model of system of professions

\begin{tabular}{|c|c|}
\hline Relevance & Criticism and Limitations \\
\hline $\begin{array}{l}\text { Abbott's theory was a fundamental paradigm } \\
\text { shift from previous sociological theories of } \\
\text { professions, as it: } \\
\text { - Shifted the unit of analysis from single } \\
\text { professions to a system of professions } \\
\text { and focusing on professional work; } \\
\text { - Shifted focus from institutional } \\
\text { structures of professions to professional } \\
\text { work; } \\
\text { Adopted an interactional and systematic } \\
\text { relations approach } \\
\text { Analysed functional divisions and the } \\
\text { forces behind jurisdictional change; } \\
\text { Considered the role of external factors } \\
\text { in shaping a field as an area of practice. }\end{array}$ & $\begin{array}{l}\text { Abbott's theory does not answer the following questions: } \\
\text { - How does a system of interdependent professions organise } \\
\text { its own coordination? } \\
\text { How do interdependent and differentiated BEPs positively } \\
\text { work together in an ecological system to complete a whole? } \\
\text { How do mutual boundaries serve as a sight of interconnection } \\
\text { rather than rivalry? } \\
\text { How do boundaries become a mode of production rather than } \\
\text { source of conflict (Lamont and Molnar, 2002; Star and } \\
\text { Giesemer, 1989)? } \\
\text { How do BEPs move from a retrograde culture of inter- } \\
\text { professional competition and turf battles towards integration } \\
\text { - relational analysis? } \\
\text { What is the role of the state in the structuring of professional } \\
\text { work? }\end{array}$ \\
\hline
\end{tabular}

\subsection{Gieryn's (1983) Boundary work as a Lens}

Several writers have used boundary work as a tool for social and cultural distinctions (Gieryn, 1983; Liu, 2013). Because professional boundaries are always contested and transformed by tensions, Gieryn (1983) encourages a focus on their construction and negotiation. In a study of the science community, Gieryn(1983) examined "the discursive attribution of selected qualities to scientists, scientific method, and scientific claims for drawing a rhetorical boundary between science and some less authoritative, residual non-science" and "demarcating, defending, expanding, contesting the limits of legitimate science, the real scientist from the pseudo scientist" territory. So, if boundaries designate the beginning and the end of territories, jurisdictional boundaries indicate the presence of borderlines that confine professional work for each BEP.

According to Liu (2013), for both Abbott and Gieryn, boundary work is not only a symbolic concept for understanding social classifications but also a spatial concept. In this sense, boundary work involves an engagement in the construction of social space, such as the space of knowledge (Gieryn, 1999) or the space of work and occupations (Abbott 1988). Accordingly, various patterns of boundary work all have spatial consequences.

Referring to the workplace, professions cannot deliver their functions independently. Instead, they become interconnected and intertwined in project organisations where they temporarily collaborate and integrate their knowledge in their delivery of projects (Abbott 1988; Bordass \& Leaman, 2013; McMurtry 2013). They form an ecology of occupations to accomplish the tasks considered to be within their jurisdiction (Janda and Killip 2010).

So, if boundaries designate the beginning and the end of territories jurisdictional boundaries indicate the presence of borderlines that confine reserved work for each BEP. The competition for tasks from time to time also differentiates the internal division of professions, thus forming jurisdictional boundaries. The differentiation creates some form of specialisation that may be a vertical stratification, thus creating hierarchy and subordination or may be horizontal, thus creating functional differentiation. As such, professions engage in jurisdictional claims and settlements. The differentiation carves out areas of specialisation for each profession but at the same time reinforces inter-professional connections amongst professions. It also highlights that the professions become "interdependent", meaning that there cannot be specialisation with some form of complementarity. Since the professions in a system are interdependence they must integrate and collaborate of which their boundaries play a role.

\section{Significance of the Theoretical Frameworks}

While theories of temporary organization design are suggestive, there is little empirical evidence showing how coordination happens in legitimizing professional work where the internal functioning will be in temporary organizational forms. It is on this basis that the authors argue that the problem of professionalism in the CI should move from a retrograde culture of inter-professional competition, that is, turf battles over-controlling of professional work, towards integration-relational analysis. It is possible to identify boundaries as a mode of production that bridges two or more professions in a system in the interdependent profession. Both Lamont and Molnar (2002) and Star and Giesemer (1989) tread boundaries as boundary objects bridging two separate professions. This conceptual position has a role to play in the division of professions.

In summary, the theory of structuring professional work in the DoEL as successfully advanced by Abbott's system of professions views professions as acting 
interdependently as wholly discrete units but does not address the coordination and integration required. This negates its full use as in addressing the implications for professionals in construction reform, and, as Banwell (1964:1, cited in Hindle 2000) observes, the addressing "the most urgent problem which confronts the CI, ... the necessity of thinking and acting as a whole).

One justification for the regulation of professions is prescribed (positive) behaviour and improving the efficiency of markets in delivering goods and services (Den Hertog, 2010; Kogan and Unt, 2008). It, therefore, makes sense that any state intervention in the professions should move beyond conflict to the integration of professional work in projects under which long term enrichment of the BE could be realised. As observed by several writers (e.g. Dingwall \& King, 1995; Dingwall 2004; Liu 2013), Abbott appears to be unable to signpost certainty concerning this factor, especially where the state is considered as another actor in the system of professions. However, Abbott proceeds to redeem this deficiency in his article on linked ecologies of professions (Abbott, 2005) where the influential roles of academisation are acknowledged and the state regulatory powers in the determination of territorial jurisdictions of each professional stake.

Lest it be assumed that Abbott's system re-emphasises and identifies power as a defining issue for professionalism, it can also mean that the state regulation of the professions and their legitimisation as enshrined in the legislation exists ostensibly to promote inefficiencies and perpetuate the 'problem of demarcation' as envisaged by Gieryn $(1983 ; 1995)$. The 'conflict perspective' advanced by Abbott inevitably negatively modifies attitudes towards differentiation and DoEL as well as the figuration of mutual boundaries running between interdependent professions to be a sight of rivalry rather than interconnection. Despite its profound challenges, Abbott's system of professions can offer rich insights and possibilities to professionalism for construction sector reform.

In conclusion, the theories of sociologies of professions and science attempt to assess the society's ability to hold expertise through BEPs as a form of DoEL in the CI. However, these fail to comprehensively analyse all the factors that influence professional work in projects as temporary organisations. The construction literature fails to assess the capacity of BEPs to behave as fragments comprehensively, hence inefficiencies in the CI. This paper helps to complete the existing arguments for professionalisation in the $\mathrm{BE}$, thus enabling these theories to further inform the state legitimation of BE professional work and underpin construction reform and development. In this circumstance, there is a need to seek to relate the phenomenology of professional practice in the temporary organisation to state regulation of reserved Built Environment professional work within the specific context of government-regulated industry development in developing countries.

\section{The South African Case Study}

As observed by Fox and Skitmore (2002), the South African approach to CI development (Department of
Public Works, RSA 1998: 1-70) has placed much more emphasis on institutional infrastructure to address its human capacity challenges, BEPs included. While significant progress has been made in the establishment of these developmental and regulatory entities, the regulatory tools largely remain undeveloped for various reasons. For example, the Construction Industry Development Board (CIDB) has not made progress on the launching of the register of professional service providers. Moreso, the sections in the Built Environment Professions Acts that prohibit the undertaking of work reserved for professions with designated professional titles have still not been promulgated since 2000. The South African BEP policy and the machinery and mechanisms put in place to realise reform are briefly outlined below.

After the first democratic elections in South Africa in 1994, the Department of Public Works formulated construction sector policies in the White Paper entitled, Creating an enabling environment for reconstruction, growth and development in the construction industry (DPW) (1999). According to the White Paper,

The strategic aim of a construction industry policy is to establish an enabling environment in which the objectives of reconstruction, development and growth are realised in the construction industry. The vision is of a construction industry policy and strategy that promotes stability, fosters economic growth and international competitiveness, creates sustainable employment and which addresses historic imbalances as it generates new industry capacity.

The Government of the Republic of South Africa also embarked on a plan to renew professions and professionalism in $\mathrm{BE}$ as it sought to rebuild the nation in the aftermath of apartheid. The Policy Framework on the Statutory Regulation of the Built Environment Professions (DPW: 1999) (BEPs Policy Framework justified the necessity of statutory regulation for the protection of the health, safety and pecuniary interests of the public and maintenance of quality standards. At the core, its statutory regulation in the BEP Policy lies a mechanism called reservation of work. The use of the term reservation of functions was subsequently changed to the identification of work (IDoW) in the Council for the Built Environment (CBE) Act, 2000 (Act No. 43 of 2000). Despite the change of terminology from the reservation of functions to IDoW, the explicit intentions remained the same, is to:

promote DoEL by recognising emerging professions and creating new categories of registration within the existing professions; and ii. effect state regulation of BEPs that will contribute to the efficiency and competitiveness of the CI

In view of the foregoing, IDoW is a mechanism arising out of the BEP Policy that is intended to provide a framework for the legitimation of the creation and renewal of professional work for BEPs in South Africa. While the BEP Policy Documents identified IDoW as a mechanism to achieve reform, it also pointed out the common unintended and even undesirable consequences of orthodox professionalism, including the creation of monopolies and stifling of competition. In shaping the future, a probing caution was thus raised in the BEP Policy Framework: that '...care must, therefore, be taken 
that reservation of functions is not a restrictive practice but rather an enabling provision' (DPW 1999, unnumbered). Though this notion is recognised in the policy framework, South Africa made policy choices to retain statutory regulation of BEPs to drive construction reform; and use IDoW as a regulatory mechanism to recognise emerging and renewed BEPs (Ministry of Public Works 1998: DPW policy, 1999).

Since the enactment of the relevant BEPs legislation, the implementation of IDoW remains unenforceable; as the relevant section in the legislation which reserve work for specific categories of registration remains un-enacted. These teething problems on policy interpretation and implementation undermine the change and reform intent in the BEPs Policy Document, i.e. recognition of new professions and transformation of the existing ones by creating new categories of registration within them.

South Africa has made these policy choices; what counts is the issue addressed in this study, it is not whether or not the statutory regulation of BEPs is a desirable policy choice. Rather, a need to address the quality of such state intervention once this policy choice is made. By quality, it is meant that there is a need to ensure that the wellintended actions of the State do not have unintended consequences or make things worse. This is critical as the positive intention of government intervention in achieving the desired change, is not always achieved. As observed by Luiz (2000:235), misdirected state intervention is possibly worse than no intervention.

\section{A Preliminary Conceptual Model for the Identification of Work}

Having identified the abovementioned theories to guide the legitimation concerning BE professional work in SA, the authors attempt to respond to the overarching aim of CIB Task Group TG84 on Construction Reform by exploring and explaining IDoW as the machinery and mechanisms that can be put in place to achieve BEP reform as a case study.

The preliminary schematic conceptual model in Figure 1 provides various analytical concepts centred around boundary margins on and within a system of the profession in a construction project. The preliminary schematic conceptual model makes a move away from use of the word 'boundary' as seen in the lenses referred to earlier on, electing instead 'boundary margin' to reflect the fact that the boundaries may not always be fused, that is interfaced but may overlap and sometimes leave gaps in between professions over and above what Abbott (1988) regards as 'vacancies'. Conceptualising the boundary zones of neighbouring professions as transition points at which transactions and exchanges take place is an essential step in understanding this constant process of birth and renewal of professions. It is clear that the role and function of boundaries in configuring BEPs need to be understood relationally to capture the means of collaboration across these boundary zones.

To help focus on collaboration, the preliminary conceptual model for the identification of work at the project level focuses on time and space logic before considering the legitimation process at the macro (policy) level. The conceptual model is based on four analytical concepts - overlaps, vacancies, interstices, interfaces overlaid in a territorial space (the fifth analytical concept) to explain how boundary margins keep professions relational, and how the dynamics of boundary work unfold in a BEP system that occupies a territorial space in a project (meso) environment.

Territories

In creating territories, professional boundaries serve as external bounding structures and serve as internal demarcation elements of any enclosure. In case of BEPs, boundaries demarcate and separate the internal arrangement of each discipline into specific professions, besides giving the territorial configuration of the enclosure of BEP. Such BEPs create boundaries, thus guarding their territories against both the unqualified and the neighbouring professions. This postulates that, at any given time, the territory of each BEP is demarcated at some definite point in space, relative to the next profession. Their localization in that space may have some "causation" effect and hence can say that they are interdependent.

Overlaps

There are possible overlaps in knowledge and jurisdiction between two or more professions in the system. Overlaps are a potential source of conflicts between professions. Ironically, the overlapping not only confirms the mutual dependence of professions in the system but also become a source of conflict.

Despite a clear recognition of commonalities, professions tend to be individualistic and, on occasion, face resistance arising out of overlaps, which ought to be a source of integration. Some professions consider their role as being infringed upon and their professional identity eroded. This creates a climate of uncertainty about the limits of their responsibilities towards accommodating integration.

Interstices

An interstitial space is the space in-between, underneath, beyond, enveloped, and outside our traditional spaces occupied by professions. In focusing on jurisdictional areas, 'small spaces' (referred to interstices) occur in between the professions. Their "smallness" inherently signifies a power issue. The 'in-between-ness' occurs because they are being surrounded by other spaces that are either more institutionalized, and therefore economically and legally powerful, or endowed with a stronger identity, and thus more recognizable or typical. Just like in the urban space analysis, rather than a mere small gap in between the BEPs, the interstice is, in fact, an active component. Interstitially also equates to emptiness. However, void also holds prospects for the birth of new professions.

Vacancy

Vacancy refers to a grey area in which any professions do not address a task and in which conflicts between two professions could arise as they compete for it. Vacancies are just like intervals in that they are not static but are continuously changing as they are being formed by evershifting demarcation within the system. The difference between vacancies and interstices being that vacancies are large enough to be occupied by emerging professions. 


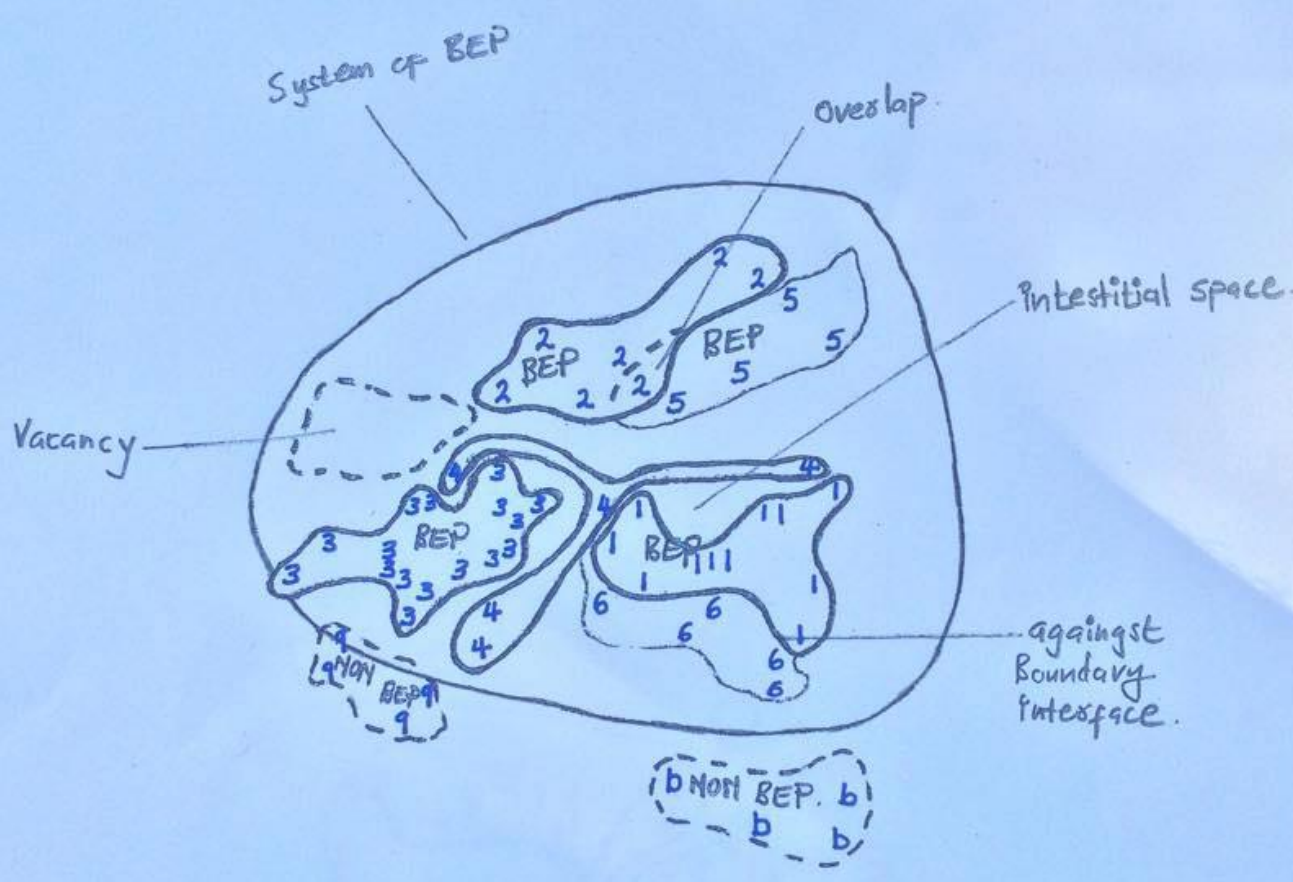

Figure 1: Preliminary conceptual model for IDoW

Please note BEP 1 to 6 represent various professions in the construction industry such as architecture, engineering, project management, etc

\section{Concluding Discussion}

The literature review shows that the CI cannot afford to institutionalise expert knowledge through BEPs without considering projects - a temporal organisation where professional work is practised- as secondary institutions, else fragmentation and poor co-ordination prevail.

Abbott's (1988) system of profession model was mobilised here as a jurisdictional sociological theory of professions to theoretically develop new insights into how professional boundary margins entangle relations and interaction of professions in space and time.

Given the pervasive role of boundaries in effecting coordination in the relations and interaction of professions, depending on the type of boundaries, the authors contend that the relationship between professions should not be left for market instruments such as contracts to define but should be part of the legitimation. Therefore, identification of work is about the legitimation of knowledge boundaries encapsulating emerging and renewed professions.

A preliminary conceptual model is proposed composed of five analytical concepts, i.e. overlaps, vacancies, interstices, interfaces, and the territorial space they exist within. Each analytical concept helps explain a unique process wherein boundaries of inter-dependent professions become legitimately entangled with another. The model highlights the process of boundary management at a project level.
Table 5: Research questions and research objectives

\begin{tabular}{|c|c|}
\hline $\begin{array}{l}\text { Specific Research } \\
\text { Questions }\end{array}$ & $\begin{array}{l}\text { Specific Research } \\
\text { Objectives }\end{array}$ \\
\hline $\begin{array}{l}\text { What is the theoretical } \\
\text { construct behind IDoW? }\end{array}$ & $\begin{array}{l}\text { To develop meaning and } \\
\text { understanding of IDoW } \\
\text { in the BE inter- } \\
\text { professional work }\end{array}$ \\
\hline $\begin{array}{l}\text { ure of } \\
\text { ins in and }\end{array}$ & $\begin{array}{l}\text { To identify key issues } \\
\text { and concerns regarding } \\
\text { boundaries in BEPs }\end{array}$ \\
\hline $\begin{array}{l}\text { Why will overlaps, gaps } \\
\text { and interstitial spaces at } \\
\text { boundary margins } \\
\text { matter? }\end{array}$ & $\begin{array}{l}\text { To describe how } \\
\text { boundary margins } \\
\text { manifest and the extent to } \\
\text { which some are more } \\
\text { influential than others }\end{array}$ \\
\hline $\begin{array}{l}\text { How can a conceptual } \\
\text { model for IDoW enable } \\
\text { and support the renewal } \\
\text { and creation of new } \\
\text { BEPs? }\end{array}$ & $\begin{array}{l}\text { To develop an } \\
\text { explanatory theory and } \\
\text { process to guide } \\
\text { identification of BE inter- } \\
\text { professional work }\end{array}$ \\
\hline
\end{tabular}

In seeking to understand the project-based professional work practices, this conceptual model opens up the black box of the legitimation of professional work. While it reveals the process at the meso level, further empirical research is required to validate the preliminary conceptual model and provide a process map for the legitimation at the macro (policy level). 
The thesis of this research is that IDoW should go beyond ruling on contested jurisdictional professional boundaries but should provide coordination and integration of differentiated but complementary functions arising out of DoEL in an interdependent and inter-BEP professional environment (rather than leave that to contractual arrangements at project stage).

Having considered the foregoing conceptual model, the main research question to be answered by the second and last phase of the study, of which the proposed conceptual model forms a part thereof, is:

What is the meaning of IDoW, and how should interprofessional work be identified for renewed and emerging professions in the $\mathrm{CI}$ ?

\section{References}

Abbott, A. (1988) The System of Professions: An Essay on the Division of Expert Labor. Chicago, IL: University of Chicago Press.

Abbott, A. (2005). Linked ecologies: States and Universities as environments for professions. Sociological Theory, 23(3): 245-274.

Adler, Kwon, and Heckscher: Professional Work: The Emergence of Collaborative Community Organization Science Vol. 19, No. 2, March-April 2008, pp. 359-376

Alashwal, A. and Abdul-Rahman, H. (2013) Developing a Conceptual Framework of Fragmentation in Construction COBRA 2013 - RICS Legal Research Symposium (Property, Construction, Planning and the Environment, available at https://www.library.auckland.ac.nz/external/finalproceed ing/Files/Papers/46530final00176.pdf

Ampofo-Anti, N. L. (2007) Highlighting the gap between critical outcomes requirements and built environment education in South Africa, in Proceedings of the second Built Environment Conference, Cape Town, South Africa, 17-19 June, 2007, pp 10

Beaton, G. (2010) Why professionalism is still relevant, http://www.professions.com.au/Files/Professionalism_B eaton.pdf, accessed on 27 September 2014

Bechky, B. A. (2006) Gaffers, gofers, and grips: Role based coordination in temporary organizations. Organization Science, 17: 3-21.

Bechky,B.A.(2003) Object Lessons: Workplace Artifacts as Representations of Occupational Jurisdiction, American Journal of Sociology 109, no. 3 (November 2003): 720-752.

Bellis, C. S. (2000) Professions in Society, BA J6 (2) 317-364

Bordass, B. and Leaman, A. (2013) A New Professionalism: Remedy or Fantasy? Building Research \& Information, 41(1), 1-7.

Brante, T.(1988). Sociological Approaches to the Professions. Acta Sociologica - ACTA SOCIOL. 31. 119142. 10.1177/000169938803100202.

Bresnen, M. and Marshall, N. (2000) Partnering in construction: a critical review of issues, problems and dilemmas". Construction Management and Economics, Vol. 18 No. 2, pp. 229-37.

Bucher, R., \& Strauss, A.L. (1961). Professions in process. American Journal of Sociology 66: 325-334.
The main research objective will be to:

To provide a theoretical understanding and conceptual framework for the identification of inter-professional work for BE Professions (BEPs)

The purpose of the study will, therefore be:

To develop a conceptual model that will assist in understanding better the intricacies involved in legitimising identified BE professional work. The specific research questions and research objectives to be answered are, therefore listed in Table 5.

Bureau, S., \& Suquet, J.B. (2009)A professionalization framework to understand the structuring of work, European Management Journal, 27 (6):467-475.

Caplow, T. (1954). The sociology of work. New York: McGraw Hill.

Chynoweth, P. (2006) The built environment interdiscipline: a theoretical model for decision makers in research and teaching, Proceedings of the International Conference on Building Education and Research (CIB W89 BEAR 2006), 10-13 April, 2006, Hong Kong Polytechnic University, Hong Kong, People's Republic of China

Chynoweth, P. (2009) The built environment interdiscipline: a theoretical model for decision makers in research and teaching', Structural Survey, Vol. 27, No. 4, Vol. 27, No. 4, pp. $301-310$.

CID(2011) Around the Commissions TG84 Construction Reform Introducing a New Task Group;https://heyblom.websites.xs4all.nl/website/newsle tter/1104/new_tg84.pdf accessed 1 June 2017

CIOB (2010) CIOB's Professionalism: An Inclusive Definition of Construction Management; http://www.ciob.org/sites/default/files/Redefining\%20Co nstruction\%20Management.pdf accessed on 8 June 2015

Gurrie, G., Koteyko, N. and Nerlich, B. (2009) The Dynamics Of Professions And Development of New Roles in Public Services Organizations: The Case Of Modern Matrons in the English NHS., Public Administration, 87: 295-311. Doi: 10.1111/J.14679299.2009.01755.X

Dainty, A., Moore, D. and Murray, M. (2006) Communication in Construction, Taylor \& Francis, New York, NY.

den Hertog, J. A. (2010) Review of economic theories of regulation, Discussion paper series/Tjalling C. Koopmans Research Institute, 10(18), 1-59, http://igiturarchive.library.uu.nl/USE/2011-0110-

200311/UUindex.html

Dingwall, R. (2004). Professions and social order in a global society. Revista Electrónica de Investigación Educativa, 6 (1). Retrieved 23 July 2018 from: http://redie.uabc.mx/vol6no1/contents-dingwall.html

Dingwall, R. (1996) Professions and social order in a global society, Plenary paper presented at the ISA Working Group 02 conference, Nottingham, UK.

Dingwall, R. and Fenn, P., 1987. A respectable profession? Sociological and economic perspectives on the regulation of professional services. International Review of Law and Economics, 7 (1), pp. 51-64. 
Dingwall, R. \& King, M. D. (1995). Herbert Spencer and the professions: occupational ecology reconsidered. Sociological Theory, 13 (1), 13-24

D’Amour, D. and Oandasan, I. (2005) Interprofessionality as the Field of Interprofessional Practice and Interprofessional Education: An Emerging Concept. Journal of Interprofessional Care, 10, 8-20.

http://dx.doi.org/10.1080/13561820500081604

Eccles, T. (2012) Occupational identity and authority in high modernity: the case of the professions in the English building industry.,

Eccles, T. S. (2009) The English building industry in late modernity: an empirical investigation of the definition, construction and meaning of profession, $\mathrm{PhD}$ thesis, London School of Economics and Political Science

Edman, J (2001). New Directions in Theorizing the Professions: The Case of Urban Planning in Sweden. Acta Sociologica, 44(4), 301-311. Retrieved from http://www.jstor.org/stable/4194895

Edwards, A. (2010). Relational agency: working with other practitioners. In Being an Expert Professional Practitioner, Anne Edwards (ed.), 6179. Netherlands: Springer.

Egan, J. (1998) Rethinking Construction, Department of the Environment, Transport and the Regions.

Eichert, J. and Kazi, A. S. (2007) Vision and strategy of Manu Build - open building manufacturing, in Kazi, A.S., Hannus, M., Boudjabeur, S. and Malone, A. (Eds), Open Building Manufacturing: Core Concepts and Industrial Requirements, Manu Build in collaboration with VTT Technical Research Centre of Finland, Espoo.

Emmerson (1962) Survey of the Problems before the Construction Industries, HMSO, London.

Evbuomwan, N. F. O. and Anumba, C. J. (1998) An Integrated Framework for Concurrent life-cycle Design and Construction, Advances in Engineering Software, 1998, vol.5, no. 7-9, pp. 587-597.

Fairclough, J. (2002) Rethinking construction innovation and research, UK: DTLR

Freidson, E. (1989) "Theory and the Professions," Indiana Law Journal: Vol. 64: Issue. 3, Article 1, Available at: http://www.repository.law.indiana.edu/ilj/vol64/iss3/1

Freidson, E. (1970) Professional Dominance: The social structure of medical care, Chicago, Illinois. Aldine

Fox, P.W. (2003) Construction Industry Development: Analysis and Synthesis of Contributing Factors, unpublished PhD Dissertation, Queensland University of Technology, Brisbane, Australia

Fox, P.W. and Skitmore, R.M. (2002) Key factors in the future development of the construction industry, Proceedings of CIB WI 07 International Conference: "Creating a sustainable construction industry in developing countries" CSIR, Pretoria, South Africa, 1113 November 2002. pp.543-553, ISBN 0-7988-5544-4

Gann, D. M. and Salter, A. J. (2000). Innovation in project-based, service-enhanced firms: The construction of complex products and systems. Research Policy.29 (78), $955-972$
Gann D. \& Salter A. (1999). Interdisciplinary skills for built environment professionals. London: The Ove Arup Foundation.

Gieryn, T. F. (1983) Boundary-work and the demarcation of science from non-science: strains and interests in professional ideologies of scientists, American Sociological Review (American Sociological Association) 48 (6): 781-795

Gieryn, T. F. (1995) Boundaries of Science. In Handbook of Science and Technology Studies, ed. Sheila Jasanoff et al., 393-443. London: Sage

Gustavsson, T\& Gohary H, (2012),"Boundary action in construction projects: new collaborative project practices", International Journal of Managing Projects in Business, Vol. 5 Iss 3 pp. 364- 37

(PDF) Boundary action in construction projects:.... Available from: https://www.researchgate.net/publication/235253541_Bo undary_action_in_construction_projects_new_collaborat ive_project_practices [accessed Jul 23 2018].

HPC (n.d) accessed January 2016; (http://www.hpcuk.org/aboutregistration/protectedtitles/protectedfunction /

Haigh, R., Amaratunga, D. (2010) An integrative review of the built environment discipline's role in the development of society's resilience to disasters, International Journal of Disaster Resilience in the Built Environment, Vol. 1 Issue: 1, pp. 11 - 24

Hartenberger, U., Lorenz, D. \& Lützkendorf, T. (2013) A shared built environment professional identity through education and training, Building Research \& Information, 41, 60-76.

Henn L. H. (2013) Moving Targets: Managing Institutional Relationships in Green Building Design and Construction, a dissertation submitted in partial fulfilment of the requirements for the degree of Doctor of Philosophy (Natural Resources and Environment) in the University of Michigan

Hermans, M van Zoest, S and Volker, L (2016) Assessing the Maturity of Public Construction Client Organisations. In: P W Chan and C J Neilson (Eds.) Proceedings of the 32nd Annual ARCOM Conference,57 September 2016, Manchester, UK, Association of Researchers in Construction Management, Vol 1,155163.

Hindle, R. D. (2015) Construction Industry Development: A role for the Built Environment Professions?, Presentation at the 4th SACPCMP Construction Management Summit on 23-24 June 2015 at Midrand, Johannesburg

Hindle, R. (2000) Construction Industry Development Though Intervention- A right and wrong way? Proceedings of the 2nd International Conference on Construction In Developing Countries, "Challenges Facing the Construction Industry In Developing Countries; 15-17 November 2000 Gaborone, Botswana, ISBN 999 12-2-156-5

Hindle, R. D (1998) A Role for the Built Environment Professions in the Development of the Construction Process, Proceedings, CIB Task Group 29 Conference on Construction in Development Countries, Arusha, Tanzania, Sept 1998, pp $87-98$ 
Hoffman, A. J. \& Henn R (2008) Overcoming the Social and Psychological Barriers to Green Building," Organization \& Environment, 21(4): 390-419.

Hughes, W. and Hughes, C. (2013) Professionalism and professional institutions in times of change, Building Research \& Information, 41 (1). pp. 28-38. ISSN 09613218 doi: $10.1080 / 09613218.2013 .737096$

Janda, K. B. and Killip, G. (2010) Building Expertise: A System of Professions Approach to Low-Carbon Practice, EASST 2010: Practicing Science and Technology, Performing the Social, Trento, Italy. European Association for the Study of Science and Technology, 2-4 Septembereich

Janda, K. B. and Killip, G. (2013) Building Expertise: Renovation as Professional Innovation, Chapter 2 in Constructing Green: The Social Structures of Sustainability. A. Hoffman and R. Henn, (eds). pp. 3555. MIT Press: Boston, USA

Johnson, T. (1972) Professions and Power, Basingstoke: The Macmillan Press Ltd.

Jones, C. \& Lichtenstein, B.B. (2008). Temporary Interorganizational Projects: How Temporal and Social Embeddedness Enhance Coordination and Manage Uncertainty. In Cropper, S., Ebers, M., Ring, P.S. \& Huxham, C. (Editors), Handbook of Interorganizational Relations: 231-255. London: Oxford University Press.

Jones, C. and Lichtenstein, B. B. (2008) Temporary Interorganizational Projects: How Temporal and Social Embeddedness Enhance Coordination and Manage Uncertainty, in Cropper, S., Ebers, M., Ring, P.S. \& Huxham, C. (Editors), Handbook of Interorganizational Relations: 231-255. London: Oxford University Press.

Kadefors, A. (2004) Trust in project relationships inside the black box, International Journal of Project Management, Vol. 22 No. 3, pp. 175-82

Karrbom, G., and Gohary, H. (2012) Boundary Action in Construction Projects: New Collaborative Project Practices, International Journal of Managing Projects in Business, 5:3.

Kogan, I. and Unt, M. (2008) The role of vocational specificity of educational credentials for labor market entry in Estonia and Slovenia, International Sociology 23(3): 389-416.

Krause, E. A. 1996. Death of the Guilds: Professions, States, and the Advance of Capitalism, 1930 to the Present. Yale University Press, New Haven.

Lamont, M and Molnár, V. (2002) The Study of Boundaries in the Social Sciences, Annual Review of Sociology, 28:167-95.

Langford, D. \& Hughes, W. (2009) Eds. Building a discipline: the story of construction management, Association of Researchers in Construction Management

Larson, M. S. (1977) The Rise of Professionalism, California: University of California Press.

Liu, S (2016), Overlapping Ecologies: Professions and Development in the Rise of Legal Services in China Sida Liu, University of Toronto UT Sociology Working Paper No. 2016-02 July 2016

Liu, S. (2015) Boundary Work and Exchange: The Formation of a Professional Service Market, Symbolic Interaction, 38: 1-21. doi: 10.1002/symb.137

Liu, S (2014), Professional Ecologies, The Wiley Blackwell Encyclopaedia of Health, Illness, Behavior, and Society, First Edition. Edited by William C. Cockerham, Robert Dingwall, and Stella R. Quah, Published 2014 by John Wiley \& Sons, Ltd

Liu, S (2013), The Legal Profession as a Social Process: A Theory on Lawyers and Globalization (August 1, 2013), Law and Social Inquiry, Vol. 38, No. 3, 2013; HLS Program on the Legal Profession Research Paper No. 2014-10, Available at SSRN: http://ssrn.com/abstract=2386293

Liu, S (2009) The logic of fragmentation: an ecological analysis of the Chinese legal services market, A Dissertation Submitted to the Faculty of the Division of the Social Sciences at the University of Chicago, in Candidacy for the Degree of Doctor of Philosophy, Department Of Sociology

Luiz,J.M (2000) The politics of state, society and economy, International Journal of Social Economics, Vol. 27 Issue: 3, pp. 227-43

Macdonald, K. M. (1995) The Sociology of the Professions, London: Sage Publications, Ltd.

McMurtry (2013) Reframing Interdisciplinary and Interprofessional Collaboration Through the Lens of Collective and Sociomaterial Theories of Learning; Issues in Interdisciplinary Studies, No. 31, Pp. 75-98 (2013)

Miller, Chris and Yusuf Ahmad (2000). 'Collaboration and Partnership: An Effective Response to Complexity and Fragmentation or Solution Built on San d?', International Journal of Sociology and Social Policy, Vol. 20, Number 5/6, pp. 1 -38

Muir, T. \& Rance, B. (1995) Collaborative practise in the built environment, London: E \& FN Spon.

Nalewaik, A., and Mills, A. (2014) The Path to Assurance: An Analysis of Project Performance Methodologies IPMA, (Ed.) Procedia - Social and Behavioural Sciences, 119, 105-114

Nawi, M. N., Baluch, N., and Bahauddin, A. Y. (2014) Impact of fragmentation issue in construction industry: An overview, in MATEC Web of Conferences (Vol. 15, p. 01009). doi:10.1051/matecconf/20141501009.

Ofori, G. . (ed.). (2011). New Perspectives on Construction in Developing Countries. Abingdon: Spon Press.

Ofori, G. (2000) Globalization and construction industry development: research opportunities, Construction Management and Economics, 18, 257-262.

Ofori, G. (1994) Establishing construction economics as an academic discipline. Construction Management and Economics, 12: 295-306.

Parsons T. ([1939] 1954) The Professions and Social Structure, in Essays in Sociological Theory, Glencoe, IL: Free Press

Powell, W. W. (1990) Neither market nor hierarchy: Network forms of organization. In B. Staw, \& R. M. Kanter (Eds.), Research in Organizational Behavior (Vol.12, p.295-336):CT,USA: JAI Press

RSA (1999) Policy Document on the Statutory Regulation of The Built Environment Professions, Department of Public Work, South Africa, Government Gazette No. 20281, June 1999

Star, S. L. and Griesemer, J. R. (1989) Institutional ecology, 'translations' and boundary objects: Amateurs and professionals, in Berkeley's Museum of Vertebrate Zoology, 1907-39. 
Stigler, George J. (1951) The division of labor is limited by the extent of the market. Journal of Political Economy 59(3):185-193.

Thomassen, M. A (2004) The economic organisation of building processes- On specialisation and coordination in interfirm relations, unpublished $\mathrm{PhD}$ thesis, Technical University of Denmark.

Tobin, J. (2015) One Design: Blurring the lines between Architecture, Engineering and Contracting, AEC bytes Building the Future, (June 29, 2015)

Turner, J.R., Müller, R., 2003. On the nature of the project as a temporary organization. Int. J. Proj. Manag. 21, 1-8

Van Wyk, L., (2006). Foresight studies and reform initiatives in construction: lessons for developing countries. CIB W107 Construction in Developing Economies Internacional Symposium "Construction in Developing Economies: New Issues Challenges" 18-20 January 2006, Santiago, Chile.
Wikforss, O . and Logren, A. (2007) Rethinking communication in construction, ITcon, Vol. 12, pp. 33745.

Wilensky, H. (1964). The professionalization of everyone? American Journal of Sociology, 70: 137-58.

Winch, G. M. (2010) Managing Construction Projects, Wiley, Hoboken, NJ.

Wood, G., McDermott, P. and Swan, W. (2002) The ethical benefits of trust-based partnering: the example of the construction industry, Business Ethics: A European Review, Vol. 11No. 1, pp. 4-13.

World Economic Forum, Shaping the Future of Construction: A Breakthrough in Mindset and Technology, 2016

Zürn, M. \& Faude, B., (2013): "On Fragmentation, Differentiation, and Coordination". In: Global Environmental Politics, Vol. 13, No. 3, S. 119-130. 